\title{
The Most Popular Measures of Genetic Similarity Based on Analyses of DNA Polymorphism
}

\section{ISSN: 2637-7659}

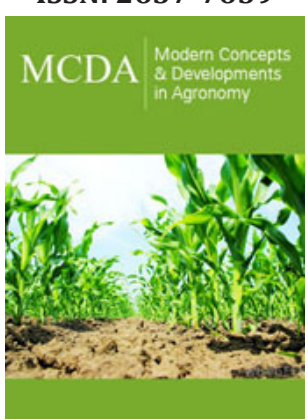

*Corresponding author: Jan Bocianowski, Department of Mathematical and Statistical Methods, Poznań University of Life Sciences, Poland

Add: ORCID: 0000-0002-0102-0084

Submission: 監 May 11, 2020

Published: 鮆 May 19, 2020

Volume 6 - Issue 3

How to cite this article: Jan Bocianowski. The Most Popular Measures of Genetic Similarity Based on Analyses of DNA Polymorphism. Mod Concep Dev Agrono. 6(3). MCDA. 000636. 2020. DOI: 10.31031/MCDA.2020.06.000636

Copyright@ Jan Bocianowski, This article is distributed under the terms of the Creative Commons Attribution 4.0 International License, which permits unrestricted use and redistribution provided that the original author and source are credited.

\section{Jan Bocianowski*}

Department of Mathematical and Statistical Methods, Poznań University of Life Sciences, Poland

\section{Opinion}

Genetic similarity of genotypes is the very important for analysis of quantitative traits in all organisms. All organisms are exposed on the influence of different environmental conditions but in the genetic level are the same in all environments. A number of studies have shown that the greater the genetic similarity of parental lines, the smaller the heterosis effect [1]. Genetic or phenotypic similarity can be estimated by genotype testing on the basis of the observations obtained through prediction (a priori) or of the observations and studies (a posteriori). Coors [2] stated that predicting the effect of heterosis between groups of germplasm showing genetic similarity of germplasm was not possible on the basis of the genetic distance determined with using the DNA markers, but should be determined in the field experiments. The paper presents five the most popular methods of estimation of genetic similarity (S) based on coefficients proposed by Jaccard, Kulczynski, Sokal and Michener, Nei as well as Rogers.

Jaccard [3]

$$
S_{J, A B}=\frac{N_{A B}}{N_{A}+N_{B}-N_{A B}}
$$

where $\mathrm{N}_{A}$-number of bands present in genotype $A, N_{B}$-number of bands present in genotype $B$, $\mathrm{N}_{\mathrm{AB}}$-number of bands present in genotypes $\mathrm{A}$ and $\mathrm{B}$.

Kulczyński [4]

$$
S_{K, A B}=\frac{N_{A B}\left(N_{A}+N_{B}\right)}{2 N_{A} N_{B}}
$$

Sokal \& Michener [5]

$$
S_{S M, A B}=\frac{N_{A B}+N_{00}}{N}
$$

where $\mathrm{N}_{00}$ number of lack of bands present in both, $\mathrm{A}$ and $\mathrm{B}$, genotypes, N-number of all markers.

Nei [6]

$$
S_{N, A B}=\frac{2 N_{A B}}{N_{A}+N_{B}}
$$




\section{Rogers [7]}

$$
S_{R, A B}=1-\frac{\left|N_{A 0}-N_{0 B}\right|}{N}
$$

Where $\mathrm{N}_{\mathrm{A} 0}$ number of band present in genotype $\mathrm{A}$ and absent in genotype $B, \mathrm{~N}_{0 \mathrm{~B}}$-number of band present in genotype $\mathrm{B}$ and absent in genotype $\mathrm{A}$.

\section{References}

1. Tomkowiak A, Bocianowski J, Kwiatek M, Kowalczewski PŁ (2020) Dependence of the heterosis effect on genetic distance, determined using various molecular markers. Open Life Sciences 15(1): 1-11.

2. Coors JG, Pandey S, Melchinger AE (1999) Genetic diversity and heterosis. In: The Genetics and Exploitation of Heterosis in Crops. American
Society of Agronomy, Crop Science Society of America, Wisconsin, USA, pp. 99-118.

3. Jaccard P (1908) Nouvelles recherches sur la distribution florale. Bull la Société vaudoise des Sci Nat 44: 223-270.

4. Kulczyński S (1927) Die Pflanzenassoziationen der Pieninen. Bull Int L Académie Pol des Sci des Lett Cl des Sci Math Nat 2: 57-203.

5. Sokal RR, Michener CD, Sokal R, Michener C, Sokal RR, et al. (1958) A statistical method for evaluating systematic relationships. Univ Kansas Sci Bull 38: 1409-1438.

6. Nei M (1972) Genetic distance between populations. The American Naturalist 106(949): 283-292.

7. Rogers JS (1972) Measures of genetic similarity and genetic distance. In: Studies in Genetics VII. University of Texas Publication, Austin, TX, USA, pp. 145-153.

\section{For possible submissions Click below:}

